\title{
EFFECT OF ADDITION DIFFERENT LEVELS OF DRIED ONION AND GARLIC ON DIGESTIBILITY, CAECOTROPHY AND CAECUM ACTIVITY OF RABBITS

\author{
El-Sayaad, G. A. E. ${ }^{1}$; A. A. Gabr ${ }^{2}$; and W. A. E. Ibrahim ${ }^{2}$ \\ ${ }^{1}$ Fac. of Agric., Benha Univ. \\ ${ }^{2}$ Fac. of Agric., Mansoura Univ.
}

\begin{abstract}
A total number of 42 male New Zealand white (NZW) rabbits at the age of 14 weeks were randomly divided into seven experimental groups (6 male for each) to study the effect of adding dried onion ( DO) and garlic (DG) on nutrients digestibility , caecotrophy and caecum activity. Rabbits were fed a basal diet supplemented with different levels of DO and DG as follows: 1) control group (CG), 2) CG+1 \% DO, 3) $\mathrm{CG}+1.5 \% \mathrm{DO}$, 4) $\mathrm{CG}+1 \% \mathrm{DG}, 5) \mathrm{CG}+1.5 \% \mathrm{DG}, 6) \mathrm{CG}+0.5 \% \mathrm{DO}+0.5 \% \mathrm{DG}, 7) \mathrm{CG}$ $+0.75 \%$ DO $+0.75 \% \mathrm{DG}$, respectively. All diets were formulated to be isonitrogenous and iso-caloric. The obtained data showed that dry matter intake did not significantly differ among dietary treatments as well as it was similar for collared rabbits compared with those uncollared. The CP digestibility coefficient was significantly $(p<0.05)$ higher for rabbits fed diets included $1.5 \%$ DG, $1.5 \%$ DO, $0.5 \%$ $\mathrm{DO}+0.5 \% \mathrm{DG}$ and $1 \% \mathrm{DG}$ than those fed either control diet or other groups. Rabbits fed $0.5 \%$ Do $+0.5 \%$ DG diet recorded significantly higher CF digestibility $(\mathrm{P}<0.05)$ than the other treated groups. The nutritive values expressed as TDN\%, DE and $\mathrm{ME} \mathrm{Kcal} / \mathrm{Kg} \mathrm{DM}$ of diet supplemented with $0.5 \% \mathrm{DO}+0.5 \%$ DG were significantly $(p<0.05)$ higher than those fed $1 \%$ Do. The DCP\% for $1.5 \% \mathrm{DO}, 1 \% \mathrm{DG}$, $1.5 \% \mathrm{DG}$ and $0.5 \% \mathrm{DO}+0.5 \% \mathrm{DG}$ diets was significantly $(\mathrm{p}<0.05)$ higher than $1 \% \mathrm{DO}$, $0.75 \% \mathrm{DO}+0.75 \% \mathrm{DG}$ and control groups. The digestibility coefficients of all nutrients as well as nutritive values of tested diets were similar between uncollared and collared groups.Treatment groups showed significant $(p<0.05)$ increase in Bacterial total count compared with the control group.
\end{abstract}

Keywords: rabbits, onion, garlic, digestibility, nutritive value, caecotrophy, caecum activity.

\section{INTRODUCTION}

Modern animal production requires the use of safe and effective additives to stimulate feed consumption and destroy harmful microorganisms of the diet, in addition to be used as rumen manipulators to increase animal productivity (Ahmed et al, 2009). Several attempts were conducted to use natural materials such as medicinal plants as feed additives could be widely accepted (line-Eric et al; 1998 and Aboul-fotouh et al; 2000). The World Health Organization (WHO) encourages using medicinal herbs and plants to substitute or minimize the use of chemicals through the global trend to go back to the nature (El-Ashry et al 2006). Many investigators reported that garlic and onion are highly inhibitory to E.coli and to other bacteria and fungi, e.g. antibacterial and antifungal (Wager et al; 1994 and Kumar and Berwal 1999). Nutritional activities of garlic and onion have been widely studied. The active inhibitory agents of garlic are allicin and/or daily thiosolphinic acid 
allicin which is enzymatically released from precursor form when the garlic and onion bulbs are crushed (Saleem and Al-Delaimy 1982). With rabbit (Elelamei 2001; Helal and Mohamed 2001; El-Hindawy et al 2003 and Abdel -Azeem and Abdel-Reheem 2006) and crossbred heifers and growing buffalo calves (Gupta et al 2005 and Aiad et al 2008). Onion and garlic supplementation showed an improvement in animal performance, gross activity of caecum or rumen microflora. However, such effects of these additives could be differ according to many variables e.g. type and level of these additive, animal species, plane of nutrition ,management conditions. Therefore, the present study was designed to evaluate the effects of onion and garlic addition as natural safe feed additives in rabbit diets on digestibility, caecotrophy status and caecum activity.

\section{MATERIALS AND METHODS}

The present study was carried out at the Rabbit's Farm, Department of Animal Production, Faculty of Agriculture, Moshtohor, Banha University, Egypt. The experiment was done during the period from May to July 2009.

\section{Experimental diets}

The composition and calculated chemical analysis of the experimental diets are presented in Table (1).

Diets were formulated by mixing dried onion (DO), dried garlic (DG) and the mixture of both at levels $1,1.5 \%,(0.5 \% \mathrm{DO}+0.5 \% \mathrm{DG})$ and $(0.75 \%$ $\mathrm{DO}+0.75 \% \mathrm{DG}$ ), respectively. Seven experimental diets were formulated to be iso-caloric and iso-nitrogenous. All diets and supplements covered the daily nutrients requirements of growing rabbits according to NRC (1977) and Cheeke (1987). Diets were pelleted at investment unit, Poultry Production Department, Faculty of Agriculture, Mansoura University, Dakahlia Governorate, Egypt.

\section{Digestibility trail and caecotrophy test.}

A total number of 84 , unsexed, New Zealand White (NZW) weaned rabbits at 5 weeks old, were randomly divided into seven experimental groups (12 rabbits each) for growing trail lasted for 5-14 weeks of age. The data of first part of this study concerning the rabbits performance and blood parameters will be presented later one (Gabr et al, 2011). Seven digestion trails and caecotrophy tests were performed. At the end of the growing trail, a total number of 42 male rabbits were selected randomly from the previous herd and fed on the same dietary treatments ( 6 male for each treatment, 3 with collar to prevent caecotrophy and 3 without collar, to allow caecotrophy) and were allotted to meet the different treatments. The rabbits were housed individually in metabolic cages with a screen allowing facilitating the collecting faeces uncontaminated with urine through the digestibility trail. Quantitative collection of faeces was started $24 \mathrm{hrs}$ after offering the daily feed. Faeces of each male were collected and feed intake was recorded daily in the morning for a collecting period 10 days was preceded by anther 7 days as a preliminary period. The same feeding regimes used during the feeding trial (5-14weeks of age) were also followed through the digestibility trail. Collected 
faeces for each male of each treatment were mixed, sprayed with $10 \%$ sulphuric acid and toluene for trapping any ammonia released, dried at $70 \mathrm{C}$ for $72 \mathrm{hrs}$; finally ground and kept for later chemical analysis. The composition of ingredients used to formulate the experimental diets and calculated chemical analysis (Table, 1) was based on the published data obtained from national research council (NRC, 1977) and Cheeke (1987) of rabbits. The determined chemical analysis of tested diets and additives are presented in Table (2). Both diet and faeces were chemically analyzed according to the conventional methods of association of official analytical chemists (A.O.A.C.2000) .Chemical analysis was done at laboratory of Anim. Prod. Dept., fac. of Agric. at Moshtohor, Banha Univ., Egypt.

\section{Caecum activity specimens}

At the end of the growing trial (14 weeks), four rabbits of each treatment were slaughtered. Samples of caecum content were taken individually from the slaughtered rabbits from each treatment after being fasted for $16 \mathrm{hrs}$. The $\mathrm{pH}$ values were determined instantly after slaughtering by inserting the $\mathrm{pH}$ probe meter eloctroid in caecal appendix contents. Afterwards, the caecal appendix fluid were taken and stored at $-20 \mathrm{C}^{\circ}$ until estimation of caecum microflora (bacteria) total count, Escherichia coli count, Salmonella and shigela. Standard methods using nutrient agar medium was used to estimate the total bacterial counts by pour plate count technique according to British Standard Institution (1991). Bacteria Coliform group were counted on MCconkey's bile medium, according to (Difco Manual, 1984).

Salt aga. Salmonella and Shigella were counted on S.S. agar medium, according to (Difco Manual, 1984).

Statistical analysis:

The obtained data were statistically analyzed using the General Linear Model (GLM) procedure described in SAS user's Guide (SAS, 2002) according to the following statistical model:

1).Digestibility data were analyzed for the effects of treatments, coprophagy and the interaction between treatments and coprophagy

$Y_{i j} k=\mu+T_{i}+C_{j}+(T C)_{i j}+E_{i j} k$

Where:

$Y_{i j} k=$ The ${ }_{i j} K^{\text {the }}$ observation $\quad \mu=$ The overall mean

$\mathrm{T}_{\mathrm{i}}=$ The fixed effect of treatment $(\mathrm{T}=1,2 \ldots \ldots, 7)$

$\mathrm{C}_{\mathrm{j}}=$ The fixed effect of coprophagy status, $(\mathrm{J}=1,2)$

$(T C)_{i j}=$ The fixed effect of interaction between $i^{\text {th }}$ treatment and $j^{\text {th }}$ coprophagy status.

$\mathrm{E}_{\mathrm{ij}} \mathrm{k}=$ Random error associated with $\mathrm{ij}^{\mathrm{th}} \mathrm{k}^{\text {observation }}$ and assumed to be independently and normally distributed (with a mean zero and variance $\partial^{2} e$ ). It includes all the other environmental and genetic factors not specific in model.

2).Caecum activity was analyzed for the effects of treatment only using the following model.

$Y_{i j}=U+T_{i}+E_{i j}$

Where:

$Y_{i j}=$ The observation on the $i^{\text {th }}$ treatment $\quad U=$ Overall mean $T_{i}=$ Effect of the $i^{\text {th }}$ treatment. $\quad E_{i j}=$ Random error treatment. 
El-Sayaad, G. A. E. et al.

Duncan's multiple range test (Duncan, 1955) was also used for the comparison among means of the experimental groups.

\section{RESULTS AND DISCUSSION}

Chemical analysis of tested diets, dried onion (DO) and garlic (DG):

The determined and calculated chemical analysis of tested diets (Table 1\&2) showed that all tested diets were practically similar, being formulated to be iso-nitrogenous and iso-caloric as designed. In addition, the chemical composition of DO and DG \% was similar in DM, OM, CP and Ash contents, while EE in DO was higher than that of DG (0.68 vs $0.25 \%$, respectively), and the reverse trend was true in case of CF (2.88 vs $5.27 \%$ ,respectively). Similar chemical analysis for DG have been recorded by Nwinuke et al (2005), Grela and Kelbaniuk (2007) and Otunola et al (2010) and for DO (Farral ,1985 and Nwinuka et al 2005).

Table (1): Calculated composition of the basal diet.

\begin{tabular}{|c|c|}
\hline Ingredients: & Quantity (\%) \\
\hline Alfalfa hay & 36 \\
\hline Yellew corn & 10 \\
\hline Soybean meal(S.B.M) & 8.6 \\
\hline Wheat bran & 31 \\
\hline Barley grains & 9.5 \\
\hline DL-methionine & 0.1 \\
\hline Molasses & 3.0 \\
\hline CaCo3 & 1.0 \\
\hline $\mathrm{NaCl}$ & 0.5 \\
\hline Vitamin and mineral premix & 0.3 \\
\hline Total & 100 \\
\hline \multicolumn{2}{|c|}{ Calculated diet composition: } \\
\hline Dry matter (D M ) \% & 91.09 \\
\hline Crude protein (\%) & 16.20 \\
\hline Ether extract (\%) & 2.79 \\
\hline Nitrogen free extract (NFE)\% & 49.9 \\
\hline Ash (\%)2 & 8.10 \\
\hline DE (Kcal /Kg diet) 5 & 2473.41 \\
\hline Crude fiber (\%) & 14.10 \\
\hline Neutral detergent fiber (NDF \%) ${ }^{*} 3$ & 38.19 \\
\hline Acid detergent fiber (ADF \%)*^ 3 & 22.29 \\
\hline Hemicellulose ( \% 4 & 15.9 \\
\hline Calcium (\%)1 & 0.956 \\
\hline Phosphorus (\%)1 & 0.527 \\
\hline Lysine (\%)1 & 0.71 \\
\hline Sulfer amino acid (S .A.A\%)1 & 0.60 \\
\hline
\end{tabular}

1. Calculated according to Cheeke (1987) 2. Calculated according to NRC 1977 ,

3. Calculated according to Pagno Toscan et al, 1986 using the following equation:

${ }^{*} \mathrm{NDF} \%=28.924+0.657$ (\% crude fiber) ${ }^{* \star}$ ADF\% $=9.432+0.912$ (\%crude fiber)

* NDF = cellulose +hemicellulose +lignin $\quad{ }^{\star \star} A D F=$ cellulose + lignin

4. Hemicellulose $(\%)=N D F-A D F$

5. Calculated according to Fekete (1987) using the following equation:

$\mathrm{DE}(\mathrm{kcal} / \mathrm{kg})=[7.1(\mathrm{CP}, \mathrm{g} / \mathrm{kg})+12(\mathrm{EE}, \mathrm{g} / \mathrm{kg})+5.59(\mathrm{NFE}, \mathrm{g} / \mathrm{kg})-1801]$ 
J. Animal and Poultry Prod., Mansoura Univ., Vol. 2 (6), June,2011

2 
Dry matter intake (DMI), digestibility and nutritive values of tested diets:

. The obtained data (Table 3 ) indicated that dry matter intake ranged between 87.5 to $105.17 \mathrm{~g}$ without significant differences among different dietary treatments. Also insignificant differences were detected between collared and uncollared rabbits. These results are in agreement with those of Ahmed et al (2005) and Dairo (2008).

Concerning nutrients digestibility coefficients, the highest significant $(p<0.05)$ value for DM was $(74.77 \%)$ recorded for group receiving $(0.5 \%$ $\mathrm{DO}+0.5 \% \mathrm{DG}$, while the lowest value was $(66.93 \%)$ recorded with rabbits fed on $1.0 \% \mathrm{DO}$. Also, the highest CP digestibility coefficients were recorded with rabbits given $1.5 \% \mathrm{DG}, 1.5 \% \mathrm{DO}, 1 \% \mathrm{DG}$ and $0.5 \% \mathrm{DO}+0.5 \% \mathrm{DG}$ diets, respectively, without significant differences among them, but they significantly higher $(p<0.05)$ than those of control, $1.0 \% \mathrm{DO}$ and $0.75 \% \mathrm{DO}+$ $0.75 \%$ DG. Digestibility coefficient of CF was significantly $(p<0.05)$ higher for rabbits fed $0.5 \% \mathrm{DO}+0.5 \% \mathrm{DG}$, than the other treated groups. The previous results are in agreement with those reported by El-Hindawy et al (2003) and Abdel-Azeem and Abdel-Reheem (2006).

As for the nutritive values of tested diets (Table 3 ) ,the highest TDN\%, DE and ME Kcal/Kg diet were recorded with $0.5 \%$ DO + $0.5 \%$ DG which was significantly higher than those of $1.0 \% \mathrm{DO}$ and $1.5 \% \mathrm{DO}$, but it was not significantly differed compared with control group, $1 \% \mathrm{DG}, 1.5 \%$ DG, and $0.75 \%$ DO + $0.75 \%$ DG . Regarding with DCP \%, the highest DCP\% values were recorded with $1.5 \%$ DG, $1.5 \%$ DO, $0.5 \%$ DO + $0.5 \%$ $D G$ and $1 \% D G$ without significant differences among them, but they were significantly $(p<0.05)$ higher than those of $1.0 \% \mathrm{DO}$, control and $0.75 \% \mathrm{DO}$ $+0.75 \%$ DG without significant differences among the latter ones. The improvements effect of DO or/and DG supplementation on nutrients digestibility and hence the nutritive values of tested diets may be due to the presence of natural substances in the DO or/and DG which enhanced the activity of enzymes responsible for the digestion of nutrients in the digestive tract (El-Hindawy et al, 2003) as well as increase beneficial microbial activity. These findings may suggest that these supplements render the feeds more available for utilization, either by affecting positively the population of microflora or improving feed utilization through slowing feed rate of passage through the digestive tract, which was reflected later in better absorption (Elelamei, 2001).

\section{Coprophagy status effects:}

All nutrients digestibility coefficients as well as nutritive values of tested diets are shown in (Table 3), for rabbits allowed for coprophagy practice (uncollared) showed similar digestibility and nutritive values like those prevented coprophagy. Similar trend was observed by Mekawy (2007).

\section{Caecum pH and microflora:}

Results in Table (4) showed that mean of $\mathrm{pH}$ values for rabbits received control diet was insignificantly higher than those of the other dietary treatments. $\mathrm{pH}$ values of caecum appendix content are within the normal ranges reported by Lebas et al (1997). Similar trend have been reported by Abdel-Azeem and Abdel-Reheem (2006). 
J. Animal and Poultry Prod., Mansoura Univ., Vol. 2 (6), June,2011

3

121 
El-Sayaad, G. A. E. et al.

Table (4): Least square means $\pm S E$ of some factors affecting Caecum activity of rabbits for the experimental diets.

\begin{tabular}{|c|c|c|c|c|}
\hline \multirow[b]{2}{*}{ Treatments } & \multicolumn{4}{|c|}{ Caecum activity } \\
\hline & $\mathrm{pH}$ & $\begin{array}{l}\text { Bacterial total } \\
\text { count }^{\star \star}\end{array}$ & $\begin{array}{c}\text { E.coli } \\
\text { total } \\
\text { count }\end{array}$ & $\begin{array}{c}\text { Salmonella } \\
\text { and shigella }\end{array}$ \\
\hline T1 Control diet & $6.13 \pm 0.040$ & $23.50 \pm 6.87^{e}$ & ND & ND \\
\hline T2 (1\% DO) & $5.94 \pm 0.040$ & $27.50 \pm 6.87 \mathrm{ed}$ & ND & ND \\
\hline T3(1.5\% DO) & $5.85 \pm 0.040$ & $172 \pm 6.87 \mathrm{~b}$ & ND & ND \\
\hline T4(1\% DG) & $5.89 \pm 0.040$ & $300.25 \pm 6.87 a$ & ND & ND \\
\hline T5(1.5\% DG) & $5.95 \pm 0.040$ & $47.50 \pm 6.87 d$ & ND & ND \\
\hline T6(0.5\% DO+0.5 \%DG) & $5.93 \pm 0.040$ & $85.00 \pm 6.87 c$ & ND & ND \\
\hline T7(0.75\% DO+ 0.75\% DG) & $5.89 \pm 0.040$ & $32.50 \pm 6.87 e d$ & ND & ND \\
\hline
\end{tabular}

$\mathrm{a}, \mathrm{b}, \mathrm{c}, \mathrm{d}, \mathrm{e}, \mathrm{f}$ and $\mathrm{g}$ Means with the same letter within each column are not significantly different.

SE=Standard error

ND=not detected

$\star *$ No. of bacterial cells / gm of caecum content (total count $\times 10^{5}$ )

Rabbits fed diet containing $1.0 \%$ DG recorded the highest means $(p<0.05)$ of total bacterial count of caecum appendix contents followed by those given $1.5 \%$ DO or $0.5 \%$ DO $+0.5 \%$ DG. The lowest means of total bacterial count were recorded by rabbits received control diet. The E.coli and Salmonella and Shigella counts seem to be undetected in all dietary treatments including control group (Table, 4). This may be due to the inclusion of the tested additives (garlic or onion) in rabbit diets, which contain active compounds such as allicin, quercetin, aflavonoid (one category of antioxidant compounds), (Abou EL-Wafa et al., 2002). As well as they are rich in fructo-oligosaccharides which can selectively influence the intestinal microflora by either encourage the growth of beneficial bacteria and inhibit pathogenic species. The absent of the E.coli and Salmonella and Shigella bacteria in control group could be hardily explained on the light of the obtained results with other dietary treatments.

\section{Conclusion}

It could be concluded that the tested botanical feed additive (dried onion or / and dried garlic) had a positive influence on most of digestibility coefficients and nutritive values of tested diets as well as showed healthy caecum activity of NZ W rabbits. The best level was mix of dried onion and dried garlic at $0.5 \%$ for each followed by $1.5 \%$ dried onion and $1.5 \%$ dried garlic.

\section{REFERENCES}

Abdel-Azeem, F. and Abdel-Reheem, M.A.T. (2006).Effect of supplemental copper and fresh garlic on performance and some biochemical changes in growing rabbits. Egyptian J. of rabbit Sci. 16(2): 341-366.

Aboul-fotouh, G.E.; Allam,S.M.; Shehata, E.I. and Abdel-Azeem, S.N.(2000). Effect of some medicinal plants as feed additives on milk production and composition of lactating buffaloes. Egyptian J. Nutrition and Feeds, 3 (1): 31-41. 
Abou EL-Wafa, S.A.; Sedki, A.A. and Ismail, A.M. (2002).Response of growing rabbits to diet containing black seed, garlic or onion as natural feed additives. Egyptian J of Rabbit-Sci, 12(1):69-83.

Ahmed, A. A.; Bassuony, Neamat I.; Awad, Set El-Habiab, S.; Aiad, A.M. and Mohamed, S.A. (2009). Adding natural juice of vegetables and fruitage to ruminant diets $(B)$ nutrients utilization, microbial safety and immunity, effect of diets supplemented with lemon, onion and garlic juice fed to growing buffalo calves. World J. of Agric. Sci., 5(4):456-465.

Ahmed, F.G.; Yacout, M.H. and Abo-Donia, F.M. (2005). Effect of using eucalyptus globules leaves in growing rabbit diets. Egyptian J. of Rabbit Sci., 15(1):1-11.

Aiad, A.M.; Bassuony, N.I.; Afifi, A.A. and Abo-Donia, F.M. (2008). Adding natural juice of vegetables and fruitage to ruminant diets: $(A)$ lemon, onion and garlic juice supplement to diets fed to suckling Buffalo calves and its effect on digestibility, growth performance and fungi count. World J. of Agric. Sci. 4(2): 149-156.

A.O.A.C. (2000). Association of Official Analytical Chemists. W. Horwitz (Editor) official methods of analysis, $13^{\text {th }}$, Washington, D.C.

British Standard Institution (1991). Microbiological examination of food and animal feeding stuff. Part I.

Cheeke, P.R. (1987). Rabbit feeding and nutrition. Academic Press. Orlndo, Florida, U.S.A.

Cheeke, P.R.; Patton, N.M. and Tempelton, G.S. (1982). Rabbit production $5^{\text {th }}$ Ed. Int. Print. and Publ. Danville II.

Dairo, F.A.S. (2008). Assessment of loofah gourd seeds luffa cylindrical (Roem) on performance and some haematological indices of rabbit weaners. $9^{\text {th }}$ World Rabbit Congress-June5 10-13, 2008- Verona-Italy.

Difco laboratories Incorporated (1984). Difco manual of dehydrated culture media and reagents for microbiological and clinical laboratory procedure, $10^{\text {th }} \mathrm{Ed}$. Michigan, USA.

Duncan, D.B. (1955). Multiple ranges and multiple F-test Biometerics,11: 142.

El-Ashry,M.A.; El-Bordeny,N.E.; Khattab,H.M. and El-Sayed,H.M (2006). Effect of diet supplemented with medicinal herbs on nutrient digestibility and some blood metabolites of buffalo calves. Egyptian $\mathrm{J}$. Nutrition and Feeds, 2: 179-191.

Elelamei, R.R. E. (2001).Evaluation of some medical plants in rabbit nutrition. M.Sc thesis, Fac. of Agric., Cairo Univ.

El-Hindawy, M.M.; Yacout, M.H.; Hassa, I.I. and ebidalla, N.A. (2003). Evalution of onion seeds as unconventional feed stuff for growing rabbit. Egyptian J. of Rabbit Sci. 13(2): 183-194.

Farral, K.T. (1985). Spices and condiments and seasoning. AVI Publishing, West Port, CT.

Fekete, S. (1987). The new Hungrain system for evaluation of feed energy. Proceedings of $1^{\text {st }}$ North American Rabbit Congress. October, 10-13, Portland-OR, USA. 
Gabr,A.A.; El-Sayaad, G.A.; Abdel-Azeem, A.F and Ibrahim, W.A.(2011). Productive performance,some blood constituents and immunological response of Rabbit fed diets supplemented with different levels of onion and garlic as safe feed additives. Egyptian J. of Nutrition and Feeds. The $13^{\text {rd }}$ conference of animal feeding, 22-25 November, Marsa Alam, Egypt.(Under publication).

Grela,E.R. and Klebaniuk R. (2007). Chemical composition of garlic preparation and its utilization in piglet diets. Medycyna Wet., 63(7): 792-795.

Gupta,N.; Kumar,A. and Tiwar, D.P. (2005). Effect of herbs as feed additives on nutrient utilization and growth in crossbred heifers fed paddy straw ration. Indian J. of Animal Sci.,75(1):52-55.

Helal, F.I.S. and Mohamed, R.S. (2001). Influence of garlic oil (Allium Sativum L.) and some of sulfur containing constituents on some biochemical changes in milk, blood and feed utilization in rabbits, with especial reference to its hypocholesterolemic activity. Egyptian $\mathrm{J}$. Nutrition and Feeds, 4:909-918.

Kumar,M. and Berwal, J.S. (1999). Sensivity of food pathogens to garlic (Allium sativum). 3 of Appl. Microbiol., 84: 213-215.

Lebas, F.: Coudert, P.: Rochambean, H. and Thebauff, R. G. (1997). Nutrition and feeding in the rabbit. Husbandry, Health and production, pp 19-21.

Line-Eric, J.; Stan Bailey, J.; Nelson, C.A.; Norman, S.J. and Thomas, T. (1998).Effect of supplemented feed on Salmonella and company lobacter population in broilers. Poultry Sci., 77:405.

Mekawy, H.M.S.H. (2007). The possibility of using irradiated untraditional feed-stuffs in rabbits nutrition. Ph.D. Thesis, Fac. Of Agric., Moshtohor, Benha univ., Egypt.

National Research Council (NRC, 1977). Nutrient requirements of domestic animals. Nutrient Requirements of Rabbits. USA National Academy of Science. Washington, D.C.

Nwinuka, N. M; Ibeh, G. O. and Ekeke, G. I. (2005). Proximate composition and levels of some toxicants in four commonly consumed spices. J. Appl. Sci. Environ. Mgt, 9(1): 150-155.

(C.F. Texetbook of rabbit medicine, Elsevier Science Limited 2002)

Otunola, G.A.; Oloyede, O.B.; Oladiji, A.T. and Afolayan, A.J. (2010). Compartive analysis of the chemical composition of three spices-Allium Sativum L. zingiber officinale Rosc. and capsicum frutescensl. commonly consumed in Nigeria. Afr. J. of Biotechnology, 9 (41):69276931.

Pagano Toscano, G.; Benatti, G. and Zoccarato, I. (1986). Comparison of crude fiber and the Van Soest detergent methods for fiber determination in rabbit feeds. J. Appl. Rabbit Res. 9: 69-75.

Pond, W.G.; Church, D.C.; Pond, K.R..and Schoknecht, P.A. (2006). Basic animal nutrition and feeding. Fifth Edition. Nice printing press, Delhi.

Saleem, Z. M. and Al-Delaimy, K.S. (1982).Inhibition of Bacillus aurous by garlic extracts. J. of food protection, 45:1007-1009.

SAS (2002). SAS user's guide Ins. Inc. Cary. NC. USA. 
Schiemann, R.; Nehring, L.; Hoffmann, W.; j. and Chudy A. (1972). Energetische Futterbewertung and Energianormen,VEB Deuischer Landwirtschafserlags, Berlin. P.72

Wager,A.; Ouaratulain,S.; Altaf, H.; Ahmed, G.M. and Ashhar,Z. (1994).Evaluation of different garlic extracts for antibacterial activity. Sci. Intl., 5:385-386.

تاثير اضافه مستويات مختلفه من البصل والثوم المجفف ومخـاليطهم على معـاملات

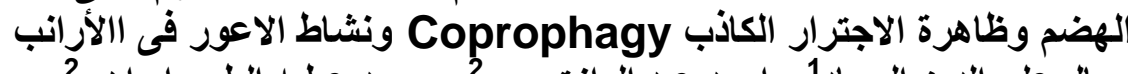

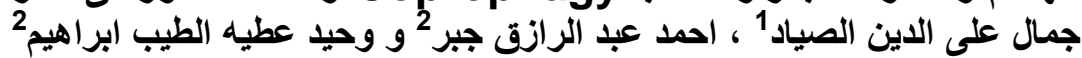

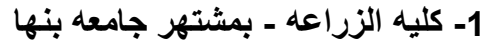

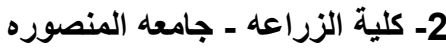

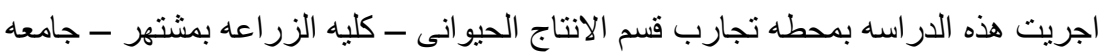

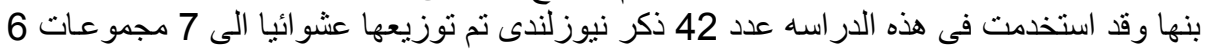

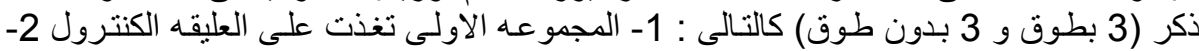

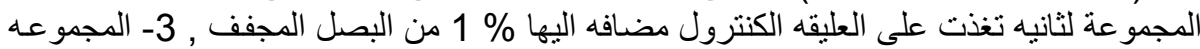

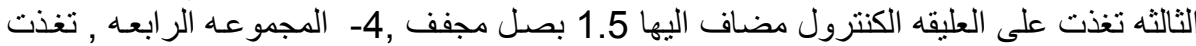

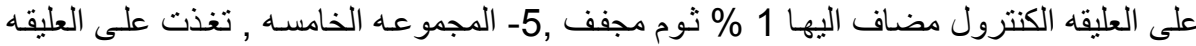

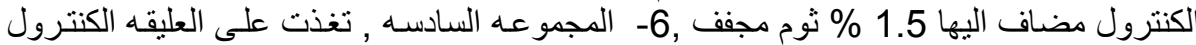

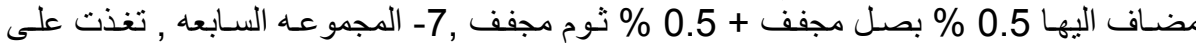

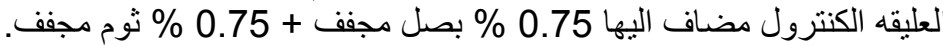
وتتلخص أهم النتائج في هذه التجربه:

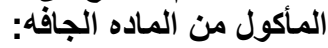

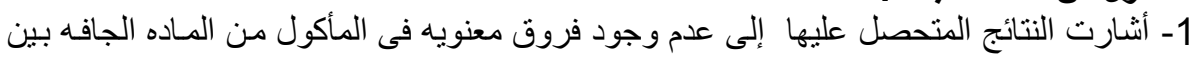

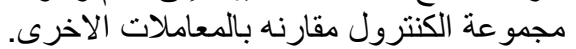

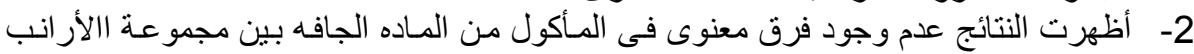

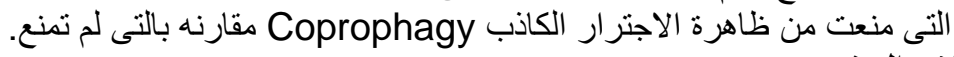

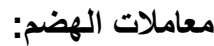

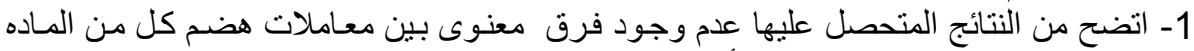

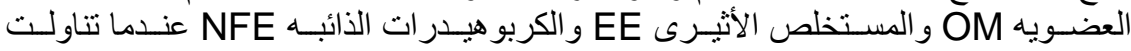
الأر انب العليقه الكنترول مقارنة بتلك التى التى تغذت على على العلائق الاخرى.

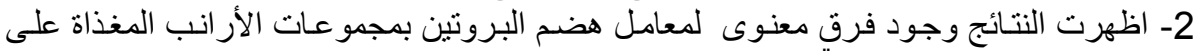

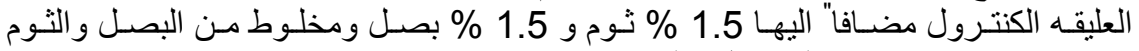

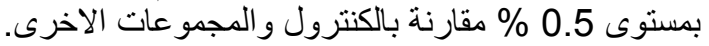

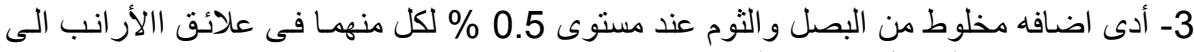

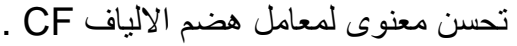

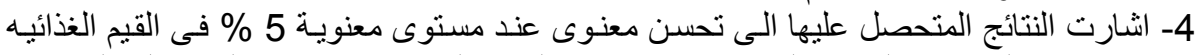

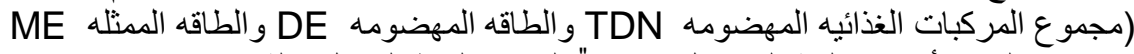
عندما تناولت الأر انب عليقة الكنترول مضافاف" اليها مخلوط البهل البهل و الثوم عند مستوى 0.5

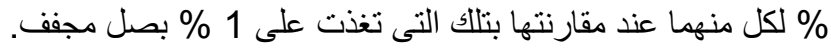

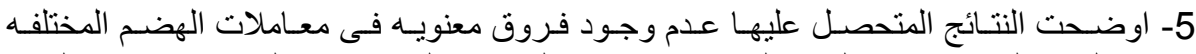

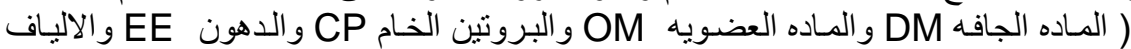

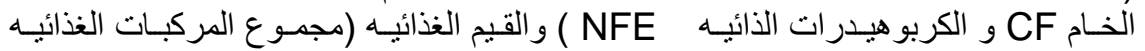


EI-Sayaad, G. A. E. et al.

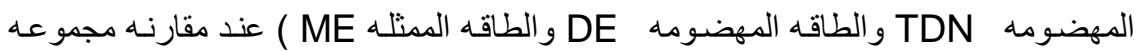

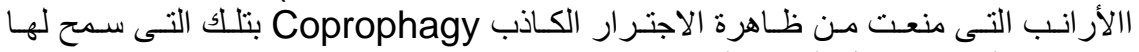
بالاجترار الكاذب (تتاول الروث الطرى).

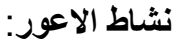

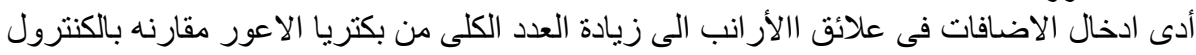

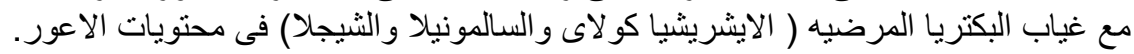

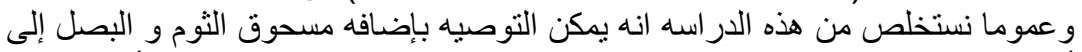

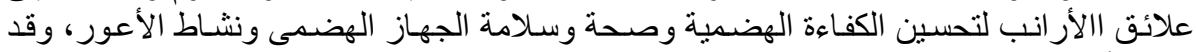

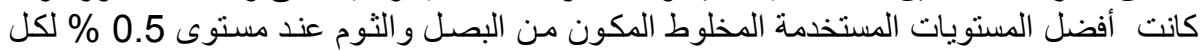

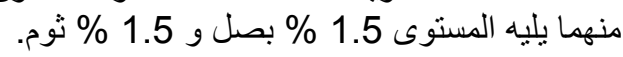

كلية الزراعة - جامعة المنصورة قام بتحكيم البحث كلية الزراعة - جامعة الازهر 
J. Animal and Poultry Prod., Mansoura Univ., Vol. 2 (6), June,2011 
Table (3): Least square means and standard errors for digestibility coefficients and nutritive values of the tested diets.

\begin{tabular}{|c|c|c|c|c|c|c|c|c|c|c|c|c|c|}
\hline \multirow[b]{3}{*}{ Items } & \multirow{3}{*}{$\begin{array}{l}\text { Control } \\
\text { diet } \\
\text { (T1) }\end{array}$} & \multicolumn{6}{|c|}{$\begin{array}{c}\text { Levels dietary treatment } \\
\end{array}$} & \multirow{2}{*}{\multicolumn{2}{|c|}{$\begin{array}{c}\text { Coprophagy } \\
\text { status }\end{array}$}} & \multirow{2}{*}{\multicolumn{2}{|c|}{ Standard errors }} & \multirow{2}{*}{\multicolumn{2}{|c|}{ Significant levels }} \\
\hline & & \multicolumn{2}{|c|}{$\begin{array}{l}\text { Level of dried } \\
\text { onion (DO) }\end{array}$} & \multicolumn{2}{|c|}{$\begin{array}{l}\text { Level of dried } \\
\text { garlic (DG) }\end{array}$} & \multicolumn{2}{|c|}{$\begin{array}{c}\text { Mixture of } \\
\text { (DO and DG) }\end{array}$} & & & & & & \\
\hline & & $\begin{array}{c}\text { T2 } \\
(1 \%)\end{array}$ & $\begin{array}{c}\text { T3 } \\
\text { (1.5\%) }\end{array}$ & $\begin{array}{c}\text { T4 } \\
(1 \%)\end{array}$ & $\begin{array}{c}\text { T5 } \\
(1.5 \%)\end{array}$ & $\begin{array}{c}\text { T6 } \\
(0.5 \%+ \\
0.5 \%)\end{array}$ & $\begin{array}{c}T 7 \\
(0.75 \%+ \\
0.75)\end{array}$ & \begin{tabular}{|l|} 
Collared \\
Rabbits
\end{tabular} & \begin{tabular}{|c} 
Un \\
collared \\
Rabbits
\end{tabular} & treatments & coprophagy & treatment & coprophagy \\
\hline \begin{tabular}{|l|}
$\begin{array}{l}\text { No. } \\
\text { rabbits }\end{array}$ \\
\end{tabular} & 6 & 6 & 6 & 6 & 6 & 6 & 6 & 21 & 21 & & & & \\
\hline \begin{tabular}{|l|} 
Dry matter \\
intake(DMI) \\
g/h/d
\end{tabular} & 105.17 & 100.83 & 91.33 & 87.5 & 101.83 & 88.67 & 92.83 & 94.96 & 96.14 & 4.99 & 2.67 & NS & NS \\
\hline
\end{tabular}

\begin{tabular}{|c|c|c|c|c|c|c|c|c|c|c|c|c|c|}
\hline \multicolumn{14}{|c|}{ Digestibility coefficients \% } \\
\hline DM & $70.64^{\mathrm{abc}}$ & $66.93^{\mathrm{c}}$ & $68.81^{\mathrm{bC}}$ & $72.49^{\mathrm{ab}}$ & $71.63^{\mathrm{ab}}$ & $74.77^{\mathrm{a}}$ & $69.47^{\mathrm{bC}}$ & 71.27 & 69.93 & 1.53 & 0.82 & * & $\mathrm{NS}$ \\
\hline OM & 71.36 & 68.19 & 69.73 & 73.13 & 71.66 & 74.96 & 71.02 & 72.04 & 70.83 & 1.45 & 0.77 & NS & NS \\
\hline CP & $68.19^{b}$ & $68.82^{b}$ & $79.54^{\mathrm{a}}$ & $78.60^{\mathrm{a}}$ & $80.11^{\mathrm{a}}$ & $79.02^{\mathrm{a}}$ & $72.54^{b}$ & 74.83 & 75.54 & 1.85 & 0.99 & $* *$ & NS \\
\hline $\mathbf{C F}$ & $52.01^{\text {bcd }}$ & $42.97^{\mathrm{d}}$ & $46.87^{\text {cd }}$ & $56.52^{b}$ & $56.22^{\mathrm{bc}}$ & $60.80^{\mathrm{a}}$ & $54.25^{\mathrm{bC}}$ & 51.41 & 55.64 & 2.98 & 1.59 & ${ }^{* *}$ & NS \\
\hline EE & 76.81 & 74.36 & 78.69 & 71.29 & 75.96 & 71.43 & 71.09 & 74.22 & 74.23 & 2.76 & 1.47 & NS & NS \\
\hline NFE & 77.89 & 75.62 & 72.82 & 76.27 & 73.13 & 76.46 & 75.54 & 75.9 & 74.87 & 1.51 & 0.81 & NS & NS \\
\hline \multicolumn{14}{|c|}{ Nutritive values $\%$} \\
\hline TDN $^{\top}$ & $66.92^{a b}$ & $62.92^{b}$ & $64.18^{b}$ & $67.29^{\mathrm{ab}}$ & $66.98^{\mathrm{ab}}$ & $69.51^{\mathrm{a}}$ & $66.13^{\mathrm{ab}}$ & 65.73 & 66.19 & 1.35 & 0.72 & * & $\mathrm{NS}$ \\
\hline DCP & $12.44^{\mathrm{b}}$ & $12.38^{b}$ & $14.47^{\mathrm{a}}$ & $14.31^{\mathrm{a}}$ & $14.58^{\mathrm{a}}$ & $14.38^{\mathrm{a}}$ & $13.20^{b}$ & 13.61 & 13.74 & 0.34 & 0.18 & ** & NS \\
\hline $\mathrm{DE}^{2}$ & $2946.67^{\text {at }}$ & $2777.33^{\circ}$ & $2853.17^{\mathrm{b}}$ & $2981.00^{\mathrm{ab}}$ & $2972.17^{\text {ab }}$ & $3076.00^{2}$ & $2921.17^{\text {abc }}$ & 2910.33 & 2954.66 & 59.08 & 31.58 & * & NS \\
\hline $\mathrm{ME}^{3}$ & $2828.66^{\text {at }}$ & $2666.17^{\circ}$ & $2739.00^{6}$ & $2861.50^{\mathrm{ab}}$ & $2853.00^{\mathrm{ab}}$ & $2953.17^{\circ}$ & $2804.33^{\text {abc }}$ & 2793.9 & 2836.33 & 56.68 & 30.29 & * & $\mathrm{NS}$ \\
\hline
\end{tabular}

$a, b$ and $c$ means within each row with different superscripts are significantly $(p<0.05)$ different. $\mathrm{NS}^{-}$not significant

1-Total digestible nutrient (TDN) was calculated according to the classic formula of (Cheeke et al, 1982) as follows:TDN\%=\%DCP+\%DCF+\%DNFE+\%DEEx2.25

2-Digestible energy (DE) was calculated according to Schiemann et al., (1972) as follows: DE (Kcal/kg diet) =5.28 (DCP, g kg) + 9.51(DEE, g/kg) $+4.20(\mathrm{DCF}, \mathrm{g} / \mathrm{kg})+4.20(\mathrm{DNFE}, \mathrm{g} / \mathrm{kg})$

3-Metabolizable energy (ME) was calculated according to (Pond et al, 2006) as follows: ME (in $\mathrm{kcal} / \mathrm{kg}$ ) =DE (in $\mathrm{kcal} / \mathrm{kg}) \times 0.96-(0.202 \times \mathrm{protein} \%) /$ 
Table (2): Chemical analysis of tested diets and natural feed additives (dried garlic DG and dried onion DO powder on DM basis \%).

\begin{tabular}{|c|c|c|c|c|c|c|c|c|c|}
\hline \multirow{3}{*}{ Items } & \multirow{3}{*}{$\begin{array}{c}\text { Control } \\
\text { diet } \\
\text { ( T1 ) } \\
\end{array}$} & \multicolumn{6}{|c|}{ Levels dietary treatments } & \multirow{2}{*}{\multicolumn{2}{|c|}{$\begin{array}{c}\text { Chemical anlysisof dried } \\
\text { garlic (DG)and dried } \\
\text { onion (DO)powder }\end{array}$}} \\
\hline & & \multicolumn{2}{|c|}{$\begin{array}{l}\text { Levels of dried } \\
\text { onion(DO) }\end{array}$} & \multicolumn{2}{|c|}{$\begin{array}{l}\text { Levels of dried } \\
\text { garlic(DG) }\end{array}$} & \multicolumn{2}{|c|}{ Mixture of (DO)and(DG) } & & \\
\hline & & $\begin{array}{c}\text { T2 } \\
(1 \%)\end{array}$ & $\begin{array}{c}\text { T3 } \\
(1.5 \%)\end{array}$ & $\begin{array}{c}\text { T4 } \\
(1 \%)\end{array}$ & $\begin{array}{c}\text { T5 } \\
(1.5 \%)\end{array}$ & $\begin{array}{c}\text { T6 } \\
(0.5 \%+0.5 \%) \\
\end{array}$ & $\begin{array}{c}\mathrm{T7} \\
(0.75 \%+0.75) \\
\end{array}$ & $\begin{array}{c}\begin{array}{c}\text { Dried garlic } \\
\text { powder }\end{array} \\
\end{array}$ & $\begin{array}{c}\text { Dried onion } \\
\text { powder }\end{array}$ \\
\hline Dry matter (DM \%) & 91.09 & 91.12 & 91.16 & 90.96 & 91.20 & 91.15 & 91.06 & 92.76 & 92.40 \\
\hline Crude protein(CP \% ) & 18.19 & 18.21 & 18.24 & 18.13 & 18.25 & 18.12 & 18.18 & 14.96 & 13.79 \\
\hline Ether extract (EE \%) & 3.13 & 2.89 & 2.85 & 2.93 & 2.88 & 2.79 & 2.95 & 0.25 & 0.68 \\
\hline Ash (\%) & 10.52 & 10.67 & 10.59 & 10.68 & 10.40 & 10.34 & 10.58 & 3.50 & 3.70 \\
\hline Organic matter (OM \%) & 89.48 & 89.33 & 89.41 & 89.32 & 89.60 & 89.66 & 89.42 & 96.50 & 96.30 \\
\hline Nitrogen free extract (NFE ) & 52.38 & 52.42 & 52.56 & 52.47 & 52.73 & 52.95 & 52.54 & 76.02 & 78.95 \\
\hline $\mathrm{DE}($ Kcal $/ \mathrm{Kg}$ diet $)$ & 2794.13 & 2768.99 & 2774.14 & 2770.90 & 2787.96 & 2780.23 & 2780.77 & 3540.68 & 3673.00 \\
\hline Crude fiber (CF \%) & 15.78 & 15.81 & 15.76 & 15.79 & 15.74 & 15.80 & 15.75 & 5.27 & 2.88 \\
\hline Neutral detergent fiber(NDF \%) & 39.29 & 39.31 & 39.28 & 39.30 & 39.27 & 39.30 & 39.27 & 32.39 & 30.82 \\
\hline Acid detergent fiber(ADF\%) & 23.82 & 23.85 & 23.81 & 23.83 & 23.79 & 23.84 & 23.80 & 14.24 & 12.06 \\
\hline Hemicellulose ( \% ) & 15.47 & 15.46 & 15.47 & 15.47 & 15.48 & 15.46 & 15.48 & 18.15 & 18.76 \\
\hline
\end{tabular}

